\title{
Digital comic design of food waste for teens
}

\author{
S. Hidayat \& D.E. Heryadi \\ Telkom University, Bandung, Indonesia
}

\begin{abstract}
Indonesia is the second biggest contributor to food waste in the world. This unstable issue is a severe problem facing Indonesia, and the younger generation must acknowledge the impact of food wastage to attain a better future. This study is based on data acquired from questionnaires, interviews, and literature reviews. The research method is qualitative, supported by theories relating to the design. The media that matches the results of the data is digital comics for teens who need to know about food waste. This digital comic media was published via the internet and received positive responses from the readers. The media-designed results are considered able to increase awareness and knowledge of adolescents about food waste in Indonesia.
\end{abstract}

Keywords: Digital Comic, Food Waste, Teenager

\section{INTRODUCTION}

The lack of awareness of the Indonesian people toward food wastage earns Indonesia second place in the world as the country with the most food waste, as reported in 2016 by The Economist Intelligent Unit (EIU) with the Barilla Center for Food and Nutrition Foundation (BCFN). Therefore, knowledge about food waste needs to be given to the people of Indonesia, especially teenagers so as to have a better impact in the long term. Adolescents tend to be influenced by the environment outside the supervision of parents and school, so it would be better if insights about food waste are also presented practically in daily activities.

Indonesia has a fan of comics since the 1930s. It started with comic strips published in newspapers and magazines. Comics in Indonesia then evolved into a Japanese style influenced by popular Indonesian publisher Elex Media Komputindo when they produced translated Japanese comics (manga) around the 2000s (Aditya \& Apsari 2019). The community's interest in comics grew in both readership and artistry, creating a large hobby and profession all over the country. As a big entertainment category in Indonesia, comics have the potential to share messages about food waste.

Currently, comic reading activities have been upgraded to digital media, including scanned comic book sites and webcomics. The website Webtoon.com is one of the most popular webcomic sites in Indonesia, with 60 million users worldwide. Through digital comics on the Webtoon website, information can be easily reached by teenagers.

\section{RESEARCH METHODS}

Comics contain the alignment of images that are deliberately arranged to convey messages and create aesthetic products to the reader (McCloud 1993). In starting the comic concepts and writing storylines, comic creators must pay attention to the limits that media has, from how far comics can visually narrate the story to how deep the message can be reached (Einser 2000). Comics also have a good communication effect, as can be seen from the combination of images and text, so messages from comics can be conveyed and presented more optimally (Lesmana et al. 2015). Comics have 
Table 1. Comparison Result between 2 Comics

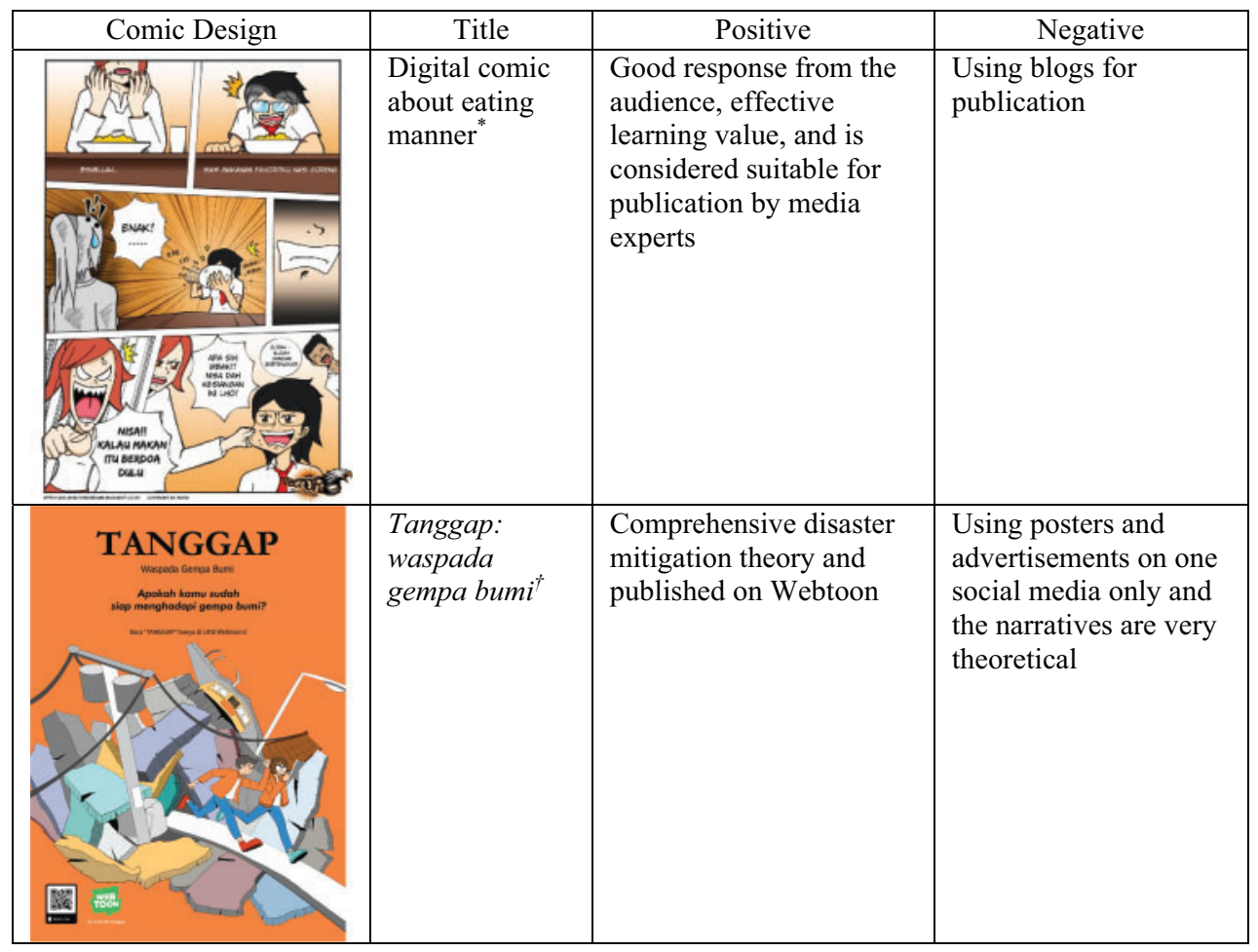

* by Muti'atul Mawaddah in 2016

$\dagger$ by Putra Arif Prasetyo in 2019

changed different mediums from time to time, with portable gadgets such as smartphones, tablets, and laptops becoming daily necessities over the last ten years. In this matter, comics have evolved into digital formats for better use. Digital comics were published online and have been accepted worldwide, especially in Asia (Aditya \&Apsari 2019). To make comics a campaign media, it is obligatory to be able to influence public behavior over a broad scope in a limited time by communication activities and media to have non-commercial benefits for society (Atkin 1989).

A comparison of similar media and themes is used in the analysis. In this case, two comics have been chosen to obtain accurate data, and the results of the analysis are shown in Table 1.

Table 1 shows how to design a better comic referring to the latest trends and community target. To deliver messages about food waste, the digital comic has to be accessed on the internet so it is easier to share on various social platforms. The comic with a lot of theory might bore the teenagers, and the comic is expected to be entertaining but still informative.

To collect data, the author distributed questionnaires to adolescents aged 12-18 and received 101 responses, and interviewed the food waste campaign Piring Bersih founder. In the questionnaire results, $66 \%$ of teen respondents said they often left their food, and the rest stated that they are not used to leaving food unfinished. The majority of the reasons expressed were because they were too full, followed by reasons such as the taste of the food, not liking a particular part of the food, they got spoiled food, or they lost the mood to eat. Furthermore, in an interview with Faulina Diani Safira as (Clean Plate) campaign founder, she explained what adolescents can do to help Indonesia avoid food waste: (1) know their food portion, (2) encourage a proper eating schedule, and (3) share what to do when they eat outside. 


\section{RESULT AND DISCUSSION}

The important role of the community in improving food sustainability in Indonesia became the main message of the comic. The form of the message is not designed too explicitly because the messages apply to entertainment media.

The title of the comic is Sepiring Liburan (A Plate of the Holiday). Each episode shows the efforts of food making, food waste side effects, and steps to reduce food waste for teenagers. The digital comic is published on an Webtoon to reach a larger audience and increase engagement (Figure 1).

The Webtoon comic Sepiring Liburan has been read by 10,800 people, followed by 698 people, and scored $9.73 / 10$ by viewers. Audiences responded through comments that they are new to the major side effects of wasting food; it showed that their sympathy toward food waste was stronger than before (Figures 2, 3).

\section{CONCLUSION}

Sepiring Liburan shares advanced knowledge about food waste so that readers can understand the dangers and be able to apply that awareness in their daily activities. The results from the comics show a very good response. Readers conveyed that they have learned lessons about food waste properly from comics and the design of this digital comic has the potential to increase awareness to reduce food waste in Indonesia.

\section{ACKNOWLEDGMENTS}

Our deepest appreciation goes to Piring Bersih as project contributor, Faulina Diani Safira as an interviewee, all the questionnaire respondents, and Webtoon readers. This article would not have been possible without their help and encouragement.
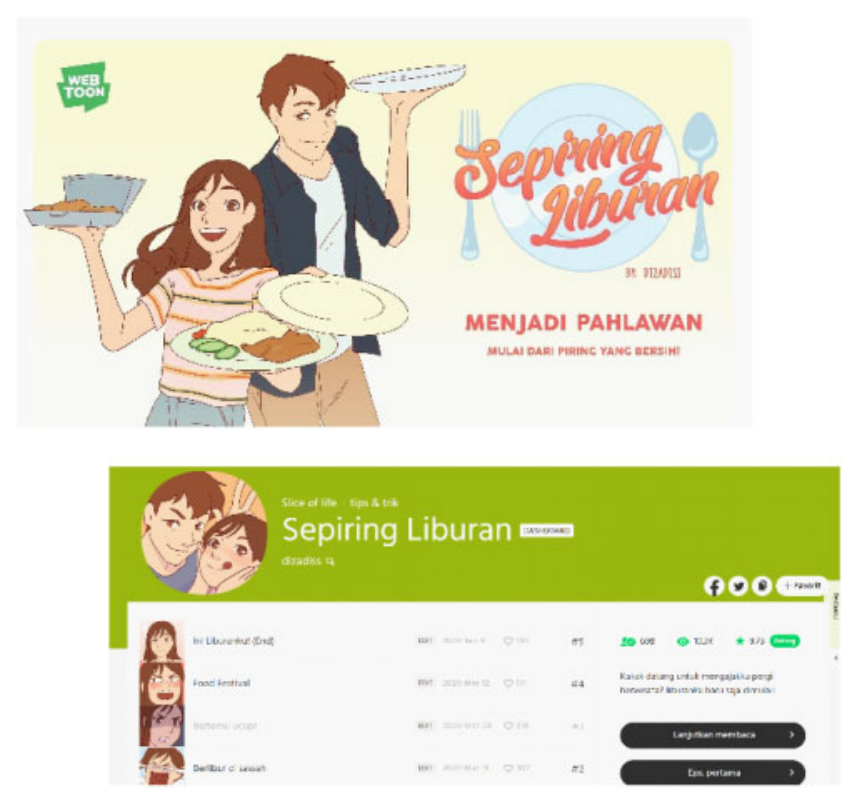

Figure 1. Webcomic digital banner and Sepiring Liburan Webtoon home page. 

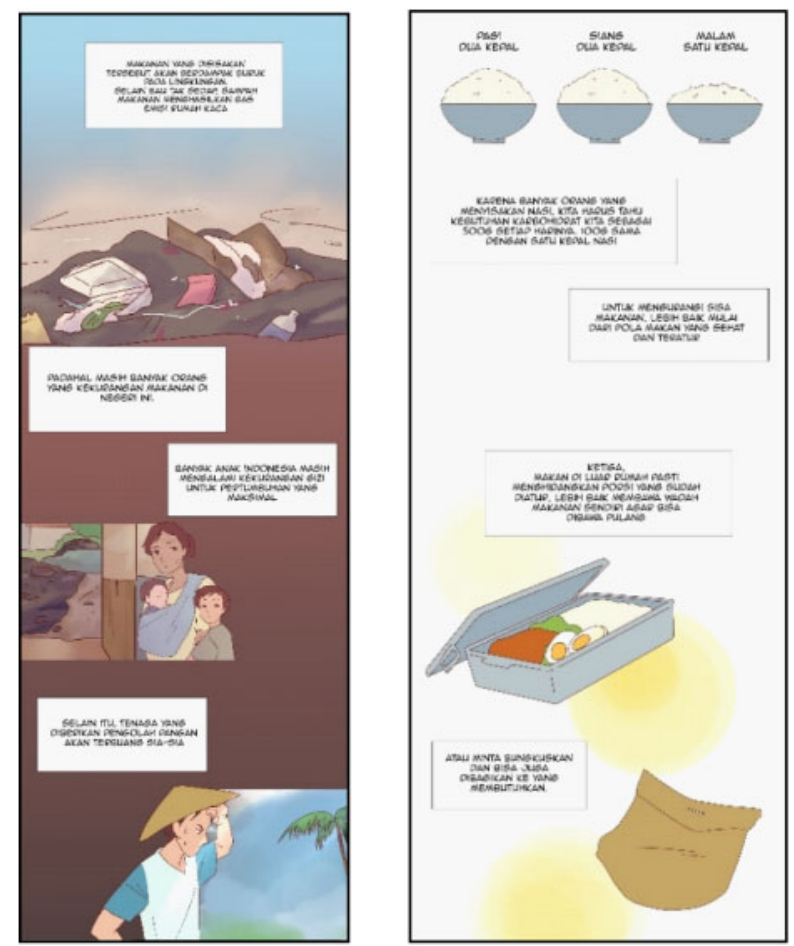

Figure 2. Sepiring Liburan comic thumbnail.

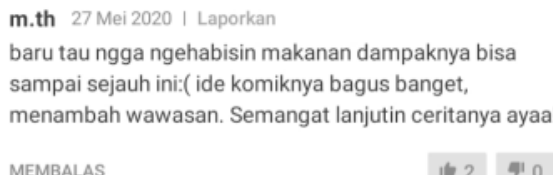

"I never knew we can get that much of a bad impact just by wasting food, this comic idea is great, really informative. Keep it up!"

E

"This is great! especially that scene where the brother said 'it takes a long time to grow a plate of rice', it caught the feeling about not wasting food and I'm moved. I think the next episode will be good too! I'm curious, keep it up!"

Figure 3. Sepiring Liburan comment section.

\section{REFERENCES}

Aditya, D. K., and Apsari, D. 2019. The influence of the advancement of social media in the visual alnguage of Indonesian comics strips. Bandung Creative Movement International Conference on Creative Industries 2018 , p. 156.

Atkin, C. K. 1989. Public Communication Campaigns. Sage Publications.

Einser, W. 2000. Comics \& Sequel Arts. Poorhouse Press.

Lesmana, M. E., Siswanto, R., and Hidayat, S. 2015. Perancangan Komunikasi Visual Komik Berbasis Cerita

Rakyat Timun Mas. EProceedings of Art \& Design, 2(1), 112.

McCloud, S. 1993. Understanding Comics: The Invisible Art. Harper Collins. 